\title{
Theoretical Approaches to Understanding the Relationship of Ideology and Everyday Life
}

\section{Yury Grigorievich Volkov}

\author{
Southern Federal University, Rostov-on-Don, Russian Federation
}

Rashid Dumalichevich Khunagov

Adyghe State University, Maikop, Russian Federation

Aues Mukhamedovich Kumykov

Kabardino-Balkaria State University, Nalchick, Russian Federation

Eugenia Sergeevna Sagalaieva

North Caucasus Federal University ( Law Institute), Stavropol, Russian Federation

Doi:10.5901/mjss.2015.v6n3s3p357

\section{Abstract}

Article is dedicated to the systematisation and synthesis of conceptual and theoretical approaches related to the clarification of the relationship of ideology and everyday life and their correlation. In addition, the article identifies the basic concepts, with theoretical and methodological importance for understanding the issues and principles of reflective analysis of the ideological everyday life. Ideology at the level of everyday life is seen in breaking through everyday human existence, being a bearer of public relations. Identification of theoretical approaches in the study of ideology in the context of everyday life allows to update subjects related to various aspects of this study and to determine the contours of its problem field when ideology at the level of everyday life is seen through the breaking of the daily existence of a human as a medium of social relations, as well as ideologically intense everyday life. Return of everyday life as the subject appears in the emphasis on everyday "establishment" of social reality in its ideological dimension. It is the coordinates of the correlation of ideology and everyday life, which can be used to construct the concept of ideological everyday life. Certain approaches to this subject can be traced in its ideology in the breaking with the semantic aspect of everyday life. Ideology is capable of forming the tissue of social reality, with ideological knowledge and values serving as important social functions, organizing, regulating, directing and integrating the activities of people in the spiritual, political, economic and social spheres of public life. The problem field of socio-philosophical reflection regarding the ideological everyday life includes the selection of theoretical research approaches and building a methodological construct, based on the conceptualization of the basic concepts and the delineation of the broad outlines of the study. The choice of the theoretical research approaches is determined by complex and multifactorial nature of the research subject - the ideological everyday life as a concept and a social phenomenon. As a result, the theoretical and methodological approach aims to understand what should and what can perform social and philosophical knowledge in a rapidly evolving social reality of the transitional Russian society.

Keywords: Ideology, everyday life, social reality, activity, ideological practices.

\section{Introduction}

Significant changes in Russia's social, political, and ideological reality, have a significant and highly complex impact on the everyday existence of a human being in society. Discursive and ideological manifestation of existence in the world of habitual and private intertwines with the actualization of the ideological discourse of everyday life in the space of the dynamics of modern social sciences and the humanities, where the semantic articulation and reassessment happens for various socially important philosophical problems.

Now the Russian society and the Russian political elite face problems associated with the search for new paths and landmarks of social development and other socio-economic and political models and institutions that would be adequate to the challenges of the contemporaneity and clearly fit into the system of ideas and thought forms as mental images caused by semantic component of social and philosophical reflection. 
Modern Russian society faces with changes of not only economic and socio-political world order, but also the daily life activity as individuals, unfolding in well-known social situations based on obvious expectations and consisting of three components - the everyday reality, everyday knowledge, and philosophy of the "common sense". In the situation of the collapse of a single behavioural code, the same acts and actions can "grow into" a number of different interpretations. The society, once united by their value foundations, attitudes and meanings, splits into groups that have lost the common language of communication.

Everyday life is constantly reproduced as a powerful and significant layer of attitudes, norms and values, where consciousness and ideological values are based on using clear, simplistic knowledge, having the character of life "recipe" in the spontaneous understanding for ongoing social processes and interpersonal relationships.

Everyday world is a reality formed by everyday consciousness, woven of its images, attitudes, and values, including ideological. Social world order, vertically organized and supported by a plurality of distinct and universally recognized norms, loses its unity and certainty. It is replaced by a set of organizational forms, having little overlapping with each other and sometimes even opposed.

Once the general socio-cultural space splits into public and private spheres that make an individual to practice and record appropriate behavioural strategies. Finding by the everyday life of qualities and properties of one of the main modes of social existence determines the setting to its reproduction in the context of the mode of existence for a human life in the world of sense as specific and universal values, and as a way to adapt to life's everyday social realities.

Conceptual and philosophical understanding and articulating of the everyday life in the context of the historical path of upcoming of the everyday problems in humanities allows reconstructing and interpreting of the bygone reality "from within", i.e., through an understanding of ways of thinking and mode of action of individuals as social actors. Daily routine may be accompanied by ideological routine as well, while ideological uniformity is none the less tiring than the monotony of everyday life.

The increased interest of the humanities to everyday life as a paradigm, culture text and the life world as a whole is due to the "uprising of the towering ordinariness", democratization and massivization of cultural complexity of social reality, where, however, the meaning of life of individuals is still evident in the usual well-known situations based on selfevident expectations.

In the socio-philosophical reflection, the theme of ideology in the context of Russian everyday life begins to take on a special urgent nature. Ideological everyday life as a concept of socio-philosophical discourse and as a social phenomenon includes the unity of individual-identification, social and practical modes-measurements. Ideological everyday life acts as manifestations of the general everyday life.

In the context of the rapid acceleration of the rhythm of life, contemporaneity inevitably and paradoxically actualizes the different forms of existence of everyday life. Everyday socio-cultural environment is changing faster than the scientific methodologies are rebuilt. Therefore, there is a need to reassess the provisions of a number of contemporary theories.

\section{Literature Review}

Everyday life is acting as a subject of philosophical reflection in the works by E. Husserl, who became the founder of the phenomenological and hermeneutical approaches to the study of this phenomenon (Husserl, 1913).

The problem of theoretical understanding of everyday life has its origins in the works by M. Weber (Weber, 1999), L. Wittgenstein (Thurman, 1980), H.-G. Gadamer (Gadamer, 2004), A. Schütz, M. Heidegger (Heidegger, 2010), where various theoretical and methodological positions are applied to the investigation of the everyday life and routine.

The social phenomenology sees everyday life as the foundation of social life and the world of common sense.

E. Husserl and A, Schütz included the concept of "life world" into scientific turnover, which became one of the first constructs to describe the space of everyday life (Ruggerone, 2012).

The last decades of the twentieth century were associated with formation of scientific fields related to the fact that the everyday life acts as a specific subject of social and humanity disciplines (German school "History of everyday life", which creators were H. Medik and A. Lüdtke; school "Micro-history" in Italy, which founders were K. Ginzburg, J. Levi, as well as E. Grendy) (Smirnov, 2013).

The domestic social and humanitarian scientific literature has many research works, which provide theoretical and methodological definitions of "everyday life", "routine", "culture of everyday life". Everyday life in the space of social interaction and in social and cultural coordinates of reality is the subject of study by such scholars as S. N. Bogolyubova (Bogolyubova, 2011), E. V. Zolotukhina-Abolina (Zolotukhina-Abolina, 2006) and many others.

The concepts by E. Durkheim, K. Mannheim, and A. Gramsci see the phenomenon of ideology, first, because of 
people living together, their natural and socio-historical circumstances. This approach defines the ideology as "false consciousness", which functional meaning is ambiguous. Durkheim interpreted ideological form as the main factor that consolidates the social system (Durkheim, 1982).

The works by M. Weber, K. Mannheim (Mannheim, 1950), R. Murton, D. S. Mill, Pareto (Pareto, 1966) discuss methodological issues of ideology and the relation of science, ideology, truth, and nature of ideology. The framework of the phenomenological direction recognises the core of ideology as the natural world and the world of life, based on everyday understanding and social attitudes (Schütz, 2004).

The domestic social thought features actively developing researches related to the analysis of various aspects of the ideological sphere in the context of incomplete development of the present post-Soviet ideological structure. The work by the Russian scientist Yu. G. Volkov is of particular interest (Volkov, 2014).

Thus, analysis of the degree of knowledge of the research topic indicates that a number of its aspects have enough scale of development in the social sciences. But most authors see these questions as secondary, and attention to them is due to and limited by the content of their own problems and study because their achievements are fragmented.

\section{Methodology}

Significant methodological role for the author belongs to the provisions and conclusions in papers by P. Bourdieu (Bourdieu, 1992), S. Bauman (Bauman, 2011), E. Giddens (Giddens, 1991), J. Habermas, which contain the provisions on fundamental life world as individualization of everyday life. This shall include a phenomenological theory of the life world by E. Husserl; procedural theory of everyday life by H.-G. Gadamer; the system theory of things J. Baudrillard (Kellner, 1994).

The use of historical-genetic analysis method enabling to identify the conceptual and categorical structure and subject area of study, which is supplemented by other approaches, based on comparisons of research and theoretical approaches, united by the themes of private life and its ideological component, was the basis for an in-depth understanding of the ideological perspective of everyday life.

Identification and systematization of the conceptual understanding of the ideological prerequisites of everyday life makes it possible to formulate a theoretical construct of the research, which is based on certain theoretical approaches as a way of conceptualizing: a) the process approach; b) ideology and value structure of everyday consciousness; c) the paradigm of symbolic politics and symbolic exchange; d) phenomenological anthropology and phenomenological psychology. This makes it possible to outline the contours of the semantic problem of the study field, and deploy the appropriate ideological concept of everyday life in the coordinates of space of the conceptual-categorical social philosophy.

\section{Results}

Ideology, along with social being, creates a vector and development trends of social consciousness, and determines the purposes and programs of social activities. In this respect, the systematization of theoretical approaches in the study of ideology in its relationship with the everyday allows emphasizing the contours of the problem field of the study. Getting to the analysis and reconstruction of the reflexive relationship ideology and everyday life, taking into account the nature of social philosophy as a special form of theoretical "care" about the person, it is necessary to pay attention to a person's ability to allocate the domain of social reality from the general structure of the universe.

The social and humanitarian thought has the developed various concepts to interpret the phenomenon of ideology.

In modern domestic and foreign literature, there are various definitions of "ideology". According to the British philosopher T. Eagleton, the lack of unity in the definition of the concept is due to the fact that the concept of ideology is the text "woven of a whole tissue of different conceptual strands; it is traced through by divergent histories, and it is probably more important to assess what is valuable or can be discarded in each of these lineages than to merge them forcibly into some Grand Global Theory" (Eagleton, 1991).

T. Eagleton systematises the basic definitions of ideology that exist in the world of philosophy: a) the process of production of ideas, knowledge, signs and values in social life; $b$ ) the set of ideas specific to individual social groups and classes; $c$ ) the system of ideas to allow legitimization of the state political power; $d$ ) the system of false ideas that help to legitimize the state political power; e) systematically biased messages; f) the form of thoughts, motivated by social interests; g) the necessary social illusions; $h$ ) the effective-focused orientation of faith, belief; i) the conditions and reasoning power; j) linguistic confusion and phenomenal reality; $k$ ) the process of turning ideas into actual social reality.

$\mathrm{K}$. Marx gave the social and political importance to ideology, seeing it as a means of maintaining antagonistic 
social order. E. Durkheim interpreted ideological forms as the main component of consolidating the social system (he preferred to use the term of "collective consciousness"). In general, the evolution of the views of socio-centrist paradigm supporters is moving to the gradual recognition of the ideology as an integral part of the social system that can be traced even in the positions of Marxist-oriented thinkers of K. Mannheim (Mannheim, 1950), A. Gramsci (Vacca, 2012). Consideration of ideology through the prism of the two approaches gives the right to claim that the ideology of sources shall be sought in the social environment, and in the psychological nature of a human being.

L. Althusser (Althusser, 2011) based on the fact that the ideology includes not only theoretical doctrine, but also "all symbolic means (ordinary notions, images, texts, etc.), by which an individual interprets their place in the social reality, acquires the sense of identity, motivation for social activity - in short, is formed as a social subject".

L. Althusser and his followers claim that ideology includes the non-reflexive structures of social imagination through which individuals "live through" their attitude to the real conditions of social existence. Ideology is defined in terms of its social and practical function, which consists in the production of the subjects of social practices (Althusser, 1993).

Socio-philosophical approach comes from the fact that ideology is a system of living knowledge of ideas, being implemented in experience and practice of both individuals and communities. Ideological knowledge and values serve as important social functions, directing the activities of people in different spheres of society.

D. B. Rezinko evaluates the phenomenon of ideology as a set of specific, ideologically conditioned, everyday human interactions, i.e. ideological practices. These practices produce a set of connections and relationships that determine the existence of the individual in the society.

Ideology at the level of everyday life is considered by us as an ideology, refracted through everyday human existence as a vehicle of social relations, as well as ideologically intense everyday life. In this sense, it is important to identify the basic approaches in the study of everyday life, ability to perform "benchmarks" for this thesis research.

The concept of "everyday life" in the Russian language means something daily, routine, and habitual. However, various sciences define the notion of "everyday life" differently.

For example, the historical sciences study which changes happened to the everyday life in the course of historical development, pay attention to the specificity of the interaction of society and the individual in the process of historical development. In addition, they study the changes on methods and techniques of historical research of everyday life, on the symbolism of the rules of conduct, deterministic by the specificity of historical conditions, and on the role of social transformations in the transformation of everyday life circumstances.

The space of a sociological study reveals directly social and cultural conditions for the functioning of everyday life and its main areas. Recently, the methodology of sociological research of the phenomenon of everyday life, the fundamental principles of coexistence of people in everyday life, and the mechanisms of social interactions becomes more and more popular (Polyakov, 2011).

Psychology is interested in individual psychological personality traits, which are embodied in everyday practices, the category of "common sense", purposeful rational behaviour, and lifestyle within everyday life.

Everyday life is a holistic social and cultural life-world, appearing in the functioning of society as "the "natural", selfevident condition of a human life" - writes N. N. Kozlova (Kozlova, 2001). B. V. Markov defines "everyday life" as selfevident reality, physical inventory; structure of anonymous practices and everydayness as opposed to festivity, savings as opposed to spending, traditional as opposed to innovation (Markov, 1999).

I. T. Karsavin and S. P. Schavelev believe that everyday life, as a problem of philosophy, is rooted in the evaluation of all the three parameters of its components. These are the everyday reality, everyday consciousness (knowledge), and the "philosophy of common sense". However, different philosophical traditions see the various objects in the phenomenon of everyday life, considering the everyday life through the various interpretations of the central philosophical categories (Karsavin, 2003).

The problem of everyday life for a long time was on the periphery of social and philosophical reflection, without any significant attention of researchers.

However, since the middle of the twentieth century, significant transformations started are occurring in the economic, social, and spiritual spheres of society, which leads to changes in everyday life. This is reflected in the following areas of philosophical thought, as a philosophy of life, phenomenology, neo-Marxism, existentialism, postmodernism, and pragmatism. A new understanding of the "human factor" in the social world and the basic existential questions of the human person appeared.

The researchers conclude that all the essential powers of the individual are as if embodied in the historical phenomenon of everyday life, and the specificity of society functioning is revealed. The representatives of various disciplines pay more and more attention to the problems of the everyday life.

However, E. Husserl in his works already draws to the idea of the "life world" by offering to abandon the perception 
of "a world in which we live" as a given one. One shall focus on the process of shaping the world in humans, based on its aspirations of all the different fantasies, doubts, reactions to the events of private life, the diversity of memories of the past and ideas about the upcoming.

The reality of everyday life is connected to the existence of the customary, familiar, lived-in world of actions, which are repeated every day. The usual order of organization and repetition of events of everyday life relates to such properties of being as routineness and trivialness.

Philosopher and culture expert Smirnov A. V. distinguishes the category of "everyday thinking", which is opposed to the rational thinking. The philosophy of everyday thinking acts as an integral part of the philosophy of the "life world" by Husserl. When studying the phenomenon of everyday life, abilities and opportunities of the consciousness to fall into a state of everyday life is emphasized (Smirnov, 2013).

In turn, reviewing the theoretical resources of political sociology of everyday life, researchers usually distinguish the two directions: frame-analytical political sociology of everyday life and political sociology of everyday practices.

As a result, the general theoretical analysis sources of everyday life include the following: a) the ideas and writings by E. Husserl and A. Schütz; b) the concept of the social construction by P. Berger and Luckman, who came to the idea that the social reality is constructed in a complex manner through the system of collective representations; $c$ ) the sociology of everyday life or "ethnomethodology", which was founded in 1960's by H. Garfinkel and A. Sikurel, and the essence of which is in finding the ways which a person enjoys in society for habitual actions; and d) theoretical developments by K. Geertz, who perceives the collection of deeds, symbols and signs in the culture, deciphering which is everyday human practices.

T. I. Yerokhina draws attention to the work, which provides a theoretical and methodological definition for the term of "everyday life" and a justification of its quality parameters and significant characteristics. To date, there are certain scientific traditions for understanding the phenomenon of everyday life. The topical areas of scientific research for verifying the definition of "everyday life" and study its content parameters and essential characteristics are the following: study of everyday practices in specific disciplines - history, philosophy, sociology, psychology, semiotics; study of social and cultural mechanisms of everyday culture; ratio analysis of the problems of everyday knowledge, philosophy and language; identification of cultural meanings of phenomena and elements of everyday life (Yerokhina, 2009).

The category of "everyday life" in philosophy aims to capture the vital human interaction with the reality, and, based on this, to explore the inner world of a human being in the everyday existence.

Everyday life emerges as the image of the world in which one can separate individual permanent foundations of the human activity (rituals, traditions, aspirations to satisfy needs, and stereotypes). The main structures of the life world are the language, norms, and interests, symbolic acts and rituals, stereotypes and prejudices - all these serve as an option for the existence of everyday relations between people.

It is the coordinates of the correlation of ideology and everyday life, which can be used to construct the concept of ideological everyday life. Certain approaches to this subject can be traced in its ideology in the breaking with the semantic aspect of everyday life.

No wonder, that M. A. Fadeicheva comes from the fact that not every ideology serves as a set of systematic exposition of theoretical positions in the treatises, manifestos, and party programs. "Unrepresented" and unnamed ideologies live in everyday life existence: in the speeches of state, political and public figures, in the mass-media, in conversations of ordinary citizens, etc., affecting the political sphere, which is called the ideological discursive practices.

V. E. Davidovich and E. V. Zolotukhina-Abolina base on the fact that the research philosophical thought is always eager to see the public consciousness as a complex set of spiritual entities, to allocate the layers, fragments, and levels within the integrity of the consciousness, to highlight the consciousness in different angles, and to detect its incarnation. Public consciousness is an independent phenomenon, differing from the individual consciousness, and at the same time, its abodes are only individual people (Davidovich, Zolotukhina-Abolina, 2004).

The same can be said about the everyday consciousness and ideology. Ideology is the result of professional work. It is a special area. However, at the same time, the ideology permeates the routine, and here and there merges with it, expresses itself not only in the speeches of professionals, but also in conversations in the kitchen, in street fights, in hopes and expectations of the "man of the street".

Everyday world is a reality formed by everyday consciousness, woven of its images, attitudes, and values. This means that we understand everyday life as such a "world of experience", in which a person acts empirically to achieve their goals, makes up a picture of reality, based on their "I" as the subjectively perceived centre, constantly communicates, often focuses in its activity using unconscious attitudes, is steeped in emotions, is busy with work, and bethinks on the level of reason. Thus, both everyday consciousness and ideology are, above all, the axiological formations. Being connected to each other, nonetheless, they orient a human being in reality in different ways, often 
coming into direct contradiction.

Based on the identified conceptual prerequisites, a research construct is made up. The basis of this study is made up from such concepts as "ideology", "everyday life", and "ideological everyday life".

Ideology. Socio-philosophical approach comes from the fact that ideology is a system of living knowledge of ideas, being implemented in experience and practice of both individuals and communities. Ideology means values, ideas, and knowledge, defining the development and establishment of social structures and social spheres. Including the system of ideas and values, ideology comes from the theoretical sphere of the social reality, forming, along with the social being, the vector of development of social consciousness, ideology of individuals, behaviour guides, and trajectory of activity, defining goals of social activities and acting as the integration and maintenance for the value-normative sample and legitimation of social relations.

L. Althusser and his followers believe that ideology includes non-reflexive structures of the social imagination through which individuals "live through" the attitude to the real conditions of their existence; and which are formed as the subjects of social action and thought. The ideas produced by the authorities and distributed by means of propaganda and agitation in the society, created the highest layer of everyday life, its organizing source. They give meaning to all human social practices, providing their living space with space closure, ordering, and completeness. Beyond this laid the realm of darkness, bourgeois chaos, and the non-existence.

The words by K. Geertz say that "ideology converts sense of the meaning and makes it available to the society" (Geertz, 1973). Ideological reality, embodied in the system of values and meanings, is largely both a symbolic space of struggle, based on the production and suggestion of mental ideological and semantic complexes in the interests of the dominant forces in the social space, and actors that use the implementation of communication strategies to try carrying out the functions of management and control by correcting trends socialization processes, forming the type and quality of value structures through the mechanisms of spiritual production.

Everyday life. The concept of "everyday life", when viewed from the standpoint of social and philosophical analysis, is close to the philosophical category of being. The thing that unites them is that both concepts refer to the existence, identifying in the world. However, with the difference that being is understood as a distinction between the real and the ideal, while the everyday routine suggests always-real existence in the world. Existence in everyday life for a human being is certainly primary in relation to everything else.

The semantics of the term reflects the current events that are taking place every day, a special rhythm of everyday life. Due to its obviousness, everyday life appears as a non-thematised area for the individual immersed in their everyday life, and it escapes their reflection. On the one hand, everyday life is a kind of social reality with own laws and principles (Berger \& Luckmann, 1966), same type repeated day after day, and, on the other hand, transforming under the influence of everyday changes. Nevertheless, everyday life is determined by certain structural elements and has certain definition.

Thus, close intertwining of different orders happens in the space of everyday life.

Everyday life is multidimensional. It contains the entire human world - from the most intimate areas shared with loved ones, to public actions; from the debasing practices to the highest forms of human activity. Everyday life in such a case confronts the dark sphere of alienation - the phenomena and things, which did not receive own name and/or rejected by the social community for political or cultural reasons. This is how the group everyday life forms, which includes jointly learned social practices (whether everyday or holiday, ritual or rationally organized, political or labour, public or intimate), tools (means) by which these practices occur; space, absorbed in the course of these practices and their semantic content to encourage them to these actions and to allow the distinction between the following: whether the action is done well or bad; to distribute deeds, things and circumstances according to their importance; to judge how suitable is the surrounding and the cultivated worlds to common ideals. Everyday life belongs to the world of culture: multi-dimensional, vertically organized, and inert (Korolev, 2013).

Ideological dimension of everyday life means that everyday practices are endowed with a certain value and meaning. Ideology permeates ordinariness, being reflected in the hopes and expectations of ordinary people.

The idéologique (or ideological saturation) of the everyday life is determined by assessing and orienting function of the consciousness, aimed at maintaining or changing the social and cultural order. Yu. G. Volkov outlines the theoretical level of ideology (Volkov, 2014), which involves operation, introduction of the personality into the consciousness and the development of fundamental values and knowledge, which are the basis of any ideology. This level is associated with the development and implementation of public knowledge and ideological values. It is suitable for mass study and implementation in the consciousness of people. This level, involves formation and functioning of ideological values at the level of everyday ideological attitudes and perceptions.

Thus, by definition, ordinary ideological representations are formed by the two ways: a) professional ideologists develop simple, basic ideological concepts and ideas, which envision a primitive level of digestion; b) ideological views 
and ideas are developed independently by individuals in the course of their everyday lives.

Accordingly, the ideological everyday life as functional area of social life finds its connotations in the values of everyday life, in the complex ideas and images in which people perceive; experience and evaluate the actual conditions of their life existence.

Noting that the when arguing about ideological everyday life, one shall be guided not by a body of texts that represents an ideology or ideological activities of institutions, but by the circumstances of everyday existence of individuals, let us give our definition of ideological everyday life.

Ideological everyday life is the life world, constructed mostly by everyday consciousness through the formation, reception and functioning of ideas, meanings, images, views and values at the level of experience and assessment of everyday life under the influence of social structure, culture, propaganda and ideological work of government and other institutions, as well as individual ideological shaping in the sphere of everyday thinking, emotions, behaviour, and communication based on the individual experience of the subjects within the boundaries of support and legitimacy (explanation and justification) of the cultural order.

The life of the consciousness is a constant everyday and ideological dynamics. In normal times, everything is filled by everyday life, and ideologies are relegated to the periphery, being the property of professionals. In times of rapid change, ideologies come to the fore and are powerfully dominant, covering the consciousness of the masses closely considerations and values of everyday life. In any case, the ideology reflects on everyday life, reflecting it and being reflected from it, being kind of a distorting mirror. Ideologies always distort everyday life, sometimes they roughen or embellish it, but they display correctly the main trends of the era: trends in the development of society, the Renaissance of the old traditions or unprecedented transformation - the trends that dwell in the consciousness are ahead of empirical daily. At that, the ideologies coexist, compete, and overcome one another.

Ideological everyday life as functional area of social life finds its reflection in the values of everyday life, in the complex ideas and images in which people perceive, experience and evaluate the actual conditions of their life existence. Ideological everyday life as a phenomenon has the tasks for construction and reproduction of social reality and sociocultural practices. Ideological dimension of everyday life means that everyday practices are endowed with a certain value and meaning.

Accordingly, the ideological everyday life acts both as a concept (discourse) and as a reality interpreted by people and having for them the status of subjective importance as the life world (a system of principles organizing social and ideological practices).

As a result, the theoretical construct serves as a tool for further analysis aimed at identifying the ideological everyday life of the Russian society by considering the logical series of scenes such as everyday life of Soviet society and its ideological dimension in the space of social and philosophical reflection; actualization of ideological discourse of everyday life in post-Soviet social reality; common sense and social knowledge in the ideological content of everyday life of the Russian society; ideological practices in the space of the Russian everyday life.

\section{Discussion}

Identification of theoretical approaches in the study of ideology in the context of everyday life allows to update subjects related to various aspects of this study and to determine the contours of its problem field when ideology at the level of everyday life is seen through the breaking of the daily existence of a human as a medium of social relations, as well as ideologically intense everyday life.

The problems connected with the everyday life are the object of attention for many scientific disciplines, which are increasingly often turning to some of its aspects. Interest of social philosophers began to concentrate more on the site of the human individual in everyday life as a world of culture, a space of activity-related and leisure practices. Return of everyday life, as the subject appears in the emphasis on everyday "establishment" of social reality in its ideological dimension.

Although everyday life is researched insufficiently, the dynamics of the representations of everyday life in the history of social and humanitarian thought can be quite clearly traced through the systematization of existing approaches and the formation of a single integrated approach to the problem. Everyday life becomes the foundation on which everything else is built. It is the coordinates of the correlation of ideology and everyday life, which can be used to construct the concept of ideological everyday life. Certain approaches to this subject can be traced in its ideology in the breaking with the semantic aspect of everyday life.

The significance of these results has significant theoretical and practical value. This is due to the following factors and circumstances. 
First, it is the changing role of everyday life in social reality in the modern Russian society.

Second, it is the rise of the ideological factor of everyday life in Russian society, which is accompanied by a delay of theoretical reflection to clarify its nature and dynamics of deployment. In such cognitive conditions, a holistic approach to the study of the ideological everyday life is required, which can contribute to social and philosophical understanding, involving an analysis of the ontological foundations, values, and social and practical significance of ideological manifestations of everyday life.

Third, the need to identify the dynamics of everyday life in the deployment of ideological processes of social and cultural changes in society, understanding the structure and modes of ideological manifestations of everyday life as the formation of social relations and values, including: everyday life ideology; everyday life ideological space as a set of ideological and semantic systems, making out and streamlining everyday life; symbolization of everyday social and cultural space associated with the ideological saturation by symbolic means (ordinary notions and images) by which individuals make sense of their place in the social reality of life and the world; ideological practices; ideologically intense social memory.

\section{References}

Althusser, L. (1993). Essays on Ideology. Verso: London \& New York.

Albaieva, I.V. (2010). The world of everyday life in a philosophical context perspective of spiritual existence. Abstract of the thesis ...Candidate of Philosophical Sciences. Ufa: Bashkir State University.

Althusser, L. (2011). Ideology and ideological apparatuses of the state. Neprikosnovennyi zapas. №. 3 (37);

Berger, P. L., Luckmann, T. (1966). The Social Construction of Reality. A Treatise on sociology of Knowl-edge. Garden City, NY: Anchor Books.

Bogoliubova, S. N. (2011) Everyday life: the space of social identity. M.: Social and humanitarian knowledge.

Bourdieu, P. \& L.J.D. Wacquant (1992). An Invitation to Reflexive Sociology. (p. 97). Chicago and London: Univ of Chicago Press.

Davidovich V. E. \& Zolotukhina-Abolina E. V. (2004). Everyday life and ideology. Philosophskiye Nauki. No. 3.

Durkheim, É. (198) The Rules of Sociological Method. New York, London, Toronto, Sydney: The Free Press. Retrieved from: http://comparsociology.com/wp-content/uploads/2013/02/Emile-Durkheim-Rules-of-Sociological-Method-1982.pdf

Eagleton, T. (1991). Ideology. (pp. 1-2, 28-29). L .; N.Y.: Verso.

Gadamer, H.-G. (2004). Truth and method. (J. Weinsheimer \& D. G. Marshall, Trans.) (p. 273). Chicago: Continuum.

Geertz, C. (1973). The Interpretation of Cultures (p. 89). N.Y.: Basic Books.

Gorshkov, M. K. (2011). Russian society as it is: (experience of sociological diagnosis). M.: Novyi Khronograph.

Griffin, Em. (2012). A First Look At Communication. New York: McGraw-Hill.

Heidegger, M. (2010). Being and Time. Albaniae: State University of New York Press.

Husserl, E. (1913). Ideen zu einer reinen Phänomenologie und phänomenologischen Philosophie: Buch 1, Allgemeine Einführung in die reine Phänomenologie. Halle/Saale. (pp.108-118).

Kasavin, I.T. (2003). Everyday life in the context of phenomenological sociology. Sotsiemy, No. 9. Retrieved from: http://csp.ispn.urfu.ru/ usul

Kellner, D. (ed.) (1994). Jean Baudrillard: A Critical Reader. Oxford: Basil Blackwell.

Korolev, S. A. (2013). Everyday life as an emanation of sociality: transformations and trends. NB: Philosophical studies. No. 8. (pp. 356422).

Kozlova, N. N. (2001). Everyday life. New Encyclopedia of Philosophy: In 4 vol. M., Vol. 3. (pp. 254-255).

Mannhaeim, K. (1950). Freedom, power and democratic planning. N.Y.: Oxford univ. press.

Mannheim, K. (1935). Ideology and Utopia. London: Routledge \& Kegan Paul.

Markov, B. V. (1966). The temple and the market. The human in the cultural space. SPb., (p. 291).

Pareto V. (1966). Sociological Writings. London: Pall Mall.

Ruggerone, L. (2013). Science and Life-World: Husserl, Schutz, Garfinkel. Human Studies. May 2013, Volume 36, Issue 2. (pp. 179197).

Schütz, A. (2004) Selection. The world shining with sense. M.: ROSSPEN.

Thurman, R. A. (1980). Philosophical Nonegocentrism in Wittgenstein and Candrakirti in Their Treatment of the Private Language Problem. Philosophy East and West, Vol. 30, No. 3.

Vacca, G. (2012). Vita e Pensieri Di Antonio Gramsci.Einaudi.Torino: Einaudi.

Volkov ,Yu. G. (2014). Russian Society: state and prospects of the ideological sphere. Social and humanitarian knowledge. No. 2.

Yerokhina, T. I. (2009). Behaviour as a sphere of actualization for "everyday life" and "routine". Yaroslavl Pedagogical Bulletin. No. 3. (pp. 157 - 158).

Zolotukhina-Abolina, E. V. (2006). Everyday life: philosophical puzzles. Kiev: Nika-Tsentr. 